\title{
Pemanfaatan Recycled Concrete Aggregate pada Beton Porous
}

\author{
Hidayat ZEN ${ }^{1}$, Gusneli YANTI ${ }^{1}$, Shanti Wahyuni MEGASARI ${ }^{1}$ \\ ${ }^{1}$ Program Studi Teknik Sipil, Fakultas Teknik, Universitas Lancang Kuning, \\ email: gusneli@unilak.ac.id
}

\author{
Sejarah artikel \\ Diserahkan: $\quad 8$ Agustus 2021 \\ Diterima: $\quad 28$ September 2021 \\ Dalam bentuk revisi: 22 September 2021 \\ Tersedia online: $\quad 30$ September 2021
}

\begin{abstract}
Recycled Concrete Aggregate (RCA) is the coarse aggregate obtained from unused concrete waste then crushed again and used as coarse aggregate in concrete mixtures. The purpose of this study is to determine the value of the compressive strength of porous concrete. This research is based on the ACI522R-10 method by varying the ratio of RCA with Normal Concrete Aggregate (NCA), namely 100\%: 0\%, 75\%: 25\%, 50\%: 50\%, 25\%: 75\%, 0\%: 100\%. The size of the gradation of coarse aggregate is 9,5-19,5 mm, the ratio of cement and coarse aggregate is 1:5 and the water-cement factor is 0,3. The additive used in the form of Sikacim Concrete Additive with the addition of 0,7\% additives. The test specimen used is in the form of a cube with dimensions of $150 \times 150 \times 150 \mathrm{~mm}$ for compressive strength testing. The result shows that the highest average compressive strength value of porous concrete specimens in a mixture variation of 25\% RCA and 75\% NCA is 5,93 MPa. The average compressive strength value of the test object meets the requirements for compressive strength of porous concrete in accordance with ACI-522R-10 which is between 2,8 - $28 \mathrm{MPa}$.
\end{abstract}

Keywords: porous concrete, flexural strength, recycled concrete aggregate, normal concrete aggregate

\begin{abstract}
Abstrak
Recycled Concrete Aggregate (RCA) adalah agregat kasar yang didapatkan dari limbah beton yang tidak terpakai kemudian dihancurkan kembali dan digunakan sebagai agregat kasar pada campuran beton. Tujuan penelitian adalah untuk mengetahui nilai kuat tekan pada beton porous. Penelitian ini berdasarkan pada metode ACI-522R-10 dengan memvariasikan perbandingan Recycled Concrete Aggregate (RCA) dengan Normal Concrete Aggregate (NCA) yaitu 100\%:0\%, 75\%: 25\%, 50\%: 50\%, 25\%:75\%,0\%: 100\%. Ukuran gradasi agregat kasar sebesar 9,5-19,5 mm, perbandingan semen dan agregat kasar sebesar 1:5 serta faktor air semen sebesar 0,3. Zat aditif yang digunakan berupa Sikacim Concrete Additive dengan penambahan aditif sebanyak 0,7\%. Benda uji yang digunakan berbentuk kubus dengan dimensi $150 \times 150 \times 150 \mathrm{~mm}$ untuk pengujian kuat tekan. Dari hasil penelitian diperoleh nilai kuat tekan rata-rata tertinggi benda uji beton porous pada variasi campuran $25 \%$ Recycled Concrete Aggregate (RCA) dan 75\% Normal Concrete Aggregate (NCA) yaitu sebesar 5,93 MPa. Nilai kuat tekan rata-rata benda uji memenuhi ke dalam persyaratan kuat tekan beton porous sesuai dengan ACI-522R-10 yaitu berada diantara 2,8 - $28 \mathrm{MPa}$.
\end{abstract}

Kata kunci: beton berpori, kuat tekan, normal concrete aggregate, recycled concrete aggregate

\section{Pendahuluan}

Perkembangan pembangunan yang pesat dan jumlah penduduk yang semakin bertambah mengakibatkan meningkatnya kebutuhan beton pada pembangunan yang akan digunakan. Perkembangan beton tersebut akan terus bertambah dan meningkat sesuai dengan 
perkembangan zaman (Latjemma, S., dkk, 2020). Seiring dengan itu, limbah beton yang dihasilkan pun semakin banyak dan bertambah. Limbah beton tersebut merupakan hasil dari pengujian, pembangunan gedung, pembongkaran gedung dan pembongkaran rigid pavement. Apabila limbah beton tersebut tidak termanfaatkan dengan baik maka dapat berdampak negatif terhadap lingkungan. Salah satu solusi untuk pemanfaatan limbah beton adalah penggunaannya sebagai material daur ulang agregat kasar dalam campuran beton yang disebut juga dengan Recycled Concrete Aggregate (RCA). Pemanfaatan limbah beton yang didaur ulang atau Recycled Concrete Aggregate (RCA) sebagai agregat dalam campuran beton bertujuan untuk menciptakan beton yang ramah terhadap lingkungan, dimana beton tersebut tersusun dari material yang tidak merusak lingkungan. Recycled concrete aggregate (RCA) adalah agregat kasar yang diperoleh dari limbah beton yang tidak terpakai lagi, kemudian dihancurkan kembali untuk digunakan sebagai agregat pada campuran beton. Agregat daur ulang ialah agregat yang didapatkan dari beton rusak (ACI Education Bulletin E1-99, 1999).

Sumber utama untuk agregat daur ulang adalah limbah konstruksi dan pembongkaran bangunan. Sebagian besar limbah tersebut dibuang begitu saja seperti halnya membuang sampah. Oleh karena itu, penggunaan limbah beton tersebut merupakan cara efektif untuk menghasilkan beton untuk konstruksi baru (Ramadevi, K. dan Chitra, R., 2017). Penggunaan material recycled aggregate dari sisa buangan konstruksi telah banyak digunakan sebagai agregat kasar yang baru karena memiliki karakteristik kekuatan tekan dan durabilitas serupa dengan agregat normal (McNeil, K. dan Kang, T. H. K., 2013) Walaupun demikian, karakteristik fisik agregat kasar recycled memiliki perbedaan mendasar dibandingkan dengan agregat kasar normal, yaitu penyerapan tinggi (sebab mortar lama masih melekat), rasio rongga udara, keausan tinggi dan bulk density rendah (Kang, Ma. dan Weibin, Li., 2018).

Beton porous merupakan beton yang ramah terhadap lingkungan yang berfungsi sebagai media penyerapan air ke dalam tanah sehingga penggunaannya dapat mengurangi resiko terjadinya genangan air di permukaan (Karimah, R., 2017). Beton porous memiliki sifat fisik dan mekanis. Sifat fisik dari beton porous yaitu porositas dan laju infiltrasi, sedangkan sifat mekanisnya ialah kuat tekan, kuat lentur, dan kuat tarik. Kuat tekan dan kuat lentur memiliki hubungan yang sangat kuat, yaitu kuat tekan berbanding lurus dengan kuat lentur (ACI 522R10, 2010). Penelitian yang dilakukan oleh Nasrul, dkk. (2021) menyatakan beton pori mempunyai hubungan yang sangat kuat antara kuat tekan dan kuat lentur, sedangkan Yanti, dkk. (2019) dalam penelitiannya menyebutkan bahwa nilai kuat lentur bertambah seiring dengan kuat tekannya.

Beton porous tersusun dari semen, agregat kasar, air dan bahan tambah (admixture) yang diinginkan. Beberapa penelitian mengenai beton yang menggunakan bahan tambah seperti dengan bahan tambah consol (Yanti, dkk., 2018), dan dengan bahan tambah SikaCim (Satrio, dkk., 2020). Dalam penelitiannya disebutkan bahwa bahan tambah dengan persentase tertentu dapat meningkatkan kuat tekan beton. Salah satu bahan tambah yang digunakan pada beton porous adalah Sikacim Concrete Additive yang termasuk dalam bahan tambah tipe F atau High Range Water Reducer (Superplasticizer) (Jamal, dkk., 2017). Keunggulan yang dimiliki oleh Sikacim Concrete Additive adalah dapat mengurangi penggunaan jumlah air hingga $20 \%$ serta dapat meningkatkan $40 \%$ kekuatan tekan pada umur 28 hari, peningkatan kedap air dan mempercepat laju peningkatan awal kekuatan tekan beton (PT. Sika Indonesia, 2019). Oleh karena itu, diperlukan penelitian untuk mengamati bagaimana pengaruh Recycled Concrete Aggregate sebagai pengganti agregat kasar terhadap kuat tekan beton porous.

\section{Metodologi}

Riset ini berupa riset eksperimen laboratorium dengan menggunakan metode (ACI Committee 522 R-10, 2010), serta material yang digunakan sebagai berikut.

a. Semen yang digunakan adalah PCC (Portland Composite Cement) produksi PT. Semen Padang

b. Air yang digunakan berasal dari sumur Laboratorium Universitas Lancang Kuning 
c. Agregat kasar berupa batu olahan crusher berupa batu pecah (split) yang telah dicuci yang berasal dari Batu Besurat, Candi Muara Takus dan recycled concrete aggregate berasal dari Laboratorium Fakultas Teknik, Universitas Lancang Kuning

d. SikaCim concrete aditive produksi PT. Sika Indonesia.

\section{Rancangan Benda Uji}

Dalam penelitian ini dilakukan penghancuran limbah beton tersebut dan kemudian dilakukan penyaringan untuk membuat ukuran agregat kasar menjadi sama besar yang berdimensi 9,519. Cetakan beton kubus yang digunakan adalah dengan ukuran $150 \times 150 \times 150 \mathrm{~mm}$. Faktor air semen (fas) digunakan sebesar 0,3. Bahan aditif berupa SikaCim Concrete Additive dipergunakan sebanyak $0,7 \%$ terhadap berat semen. Setelah itu, maka jumlah air dapat dikurangi hingga 20\%, yang mana sesuai dengan rekomendasi penggunaan SikaCim Concrete Additive.

\section{Pembuatan dan Perawatan Benda Uji}

Pembuatan benda uji bertujuan untuk memeriksa kuat tekan beton porous. Benda uji yang dibuat berbentuk kubus yang berukuran $150 \times 150 \times 150 \mathrm{~mm}$ dengan perbandingan semen dan agregat 1: 5 dan jumlah benda uji sebanyak 15 sampel. Setelah benda uji dibuat, dilakukan perawatan dengan cara direndam selama 28 hari.

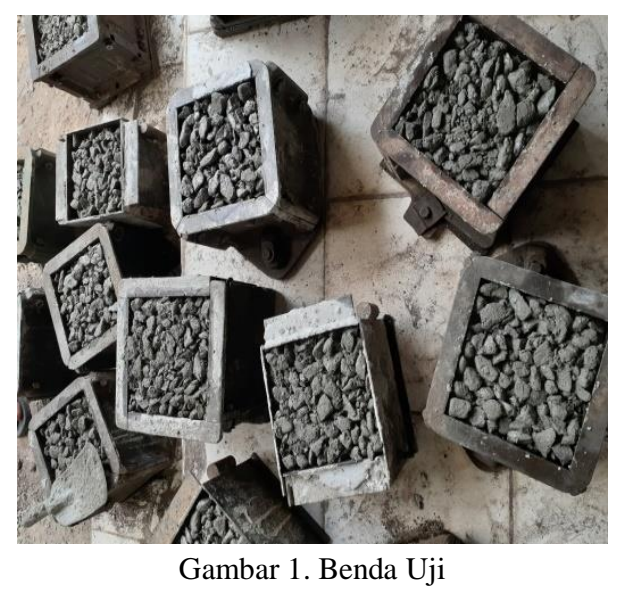

\section{Pengujian Benda Uji}

Pengujian terhadap sampel atau benda uji dilakukan setelah sampel beton porous telah mencapai umur 28 hari. Pengujian yang dilakukan adalah berupa pengujian kuat tekan menggunakan alat uji tekan (compression testing machine). Pengujian ini dilakukan untuk mengetahui nilai kuat tekan pada beton porous. Kekuatan terhadap tekan beton diperoleh dari pembebanan yang dilakukan oleh gaya tertentu yang hasilkan oleh mesin tekan sehingga dapat menyebabkan benda uji hancur. Nilai kekuatan terhadap tekan dihitung berdasarkan (SNI 1974, 2011) dengan Persamaan 1 berikut ini:

$$
f^{\prime} c=\frac{P}{A}
$$

\section{Hasil dan Pembahasan \\ Campuran Beton (Mix Design)}

Berdasarkan hasil pengujian pendahuluan agregat di laboratorium, maka direncanakan campuran beton porous untuk $1 \mathrm{~m}^{3}$. Menggunakan perbandingan 1:4 dan faktor air semen (fas) sebesar 0,3, diperoleh penggunaan semen (PCC) dalm campuran ini sebanyak $353 \mathrm{~kg} / \mathrm{m}^{3}$. Agregat yang digunakan berukuran 9,5-19 mm seberat $1470 \mathrm{~kg}$, air sebanyak $105 \mathrm{lt} / \mathrm{m}^{3} \mathrm{serta}$ bahan tambah aditif Sikacim Concrete Additive produksi PT. Sika Indonesia. 


\section{Kuat Tekan}

Pengujian kuat tekan bertujuan untuk mengetahui nilai kuat tekan beton pada saat diberi beban. Nilai kuat tekan didapat dari nilai rata-rata 3 buah benda kubus yang berukuran $150 \times 150 \times 150$ $\mathrm{mm}$ yang direndam selama 28 hari. Berdasarkan hasil pengujian pada keseluruhan benda uji dan seperti yang terlihat pada gambar 2. Hasil pengujian kuat tekan dapat dilihat pada Tabel 1.

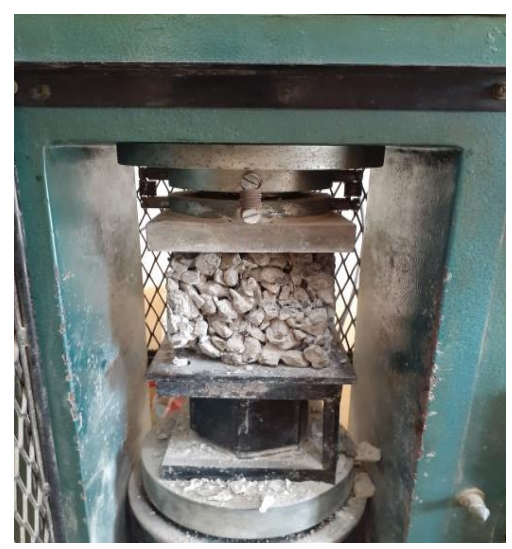

Gambar 2. Pengujian kuat tekan

Tabel 1. Hasil uji kuat tekan beton

\begin{tabular}{|c|c|c|}
\hline \multicolumn{2}{|c|}{ Komposisi Agregat Kasar (\%) } & \multirow{2}{*}{$\begin{array}{c}\text { Kuat Tekan } \\
\text { Rata-rata } \\
(\mathrm{MPa})\end{array}$} \\
\hline $\mathrm{NCA}$ & RCA & \\
\hline (1) & (2) & (3) \\
\hline 100 & 0 & 4,25 \\
\hline 75 & 25 & 5,93 \\
\hline 50 & 50 & 3,92 \\
\hline 25 & 75 & 4,89 \\
\hline 0 & 100 & 5,63 \\
\hline
\end{tabular}

Pada Tabel 1 didapatkan hasil kuat tekan tertinggi pada campuran 75\% NCA : 25\% RCA dengan kuat tekan rata-rata sebesar 5,93 $\mathrm{MPa}$ dengan fas 0,3 dan penambahan aditif sebesar $0,7 \%$.

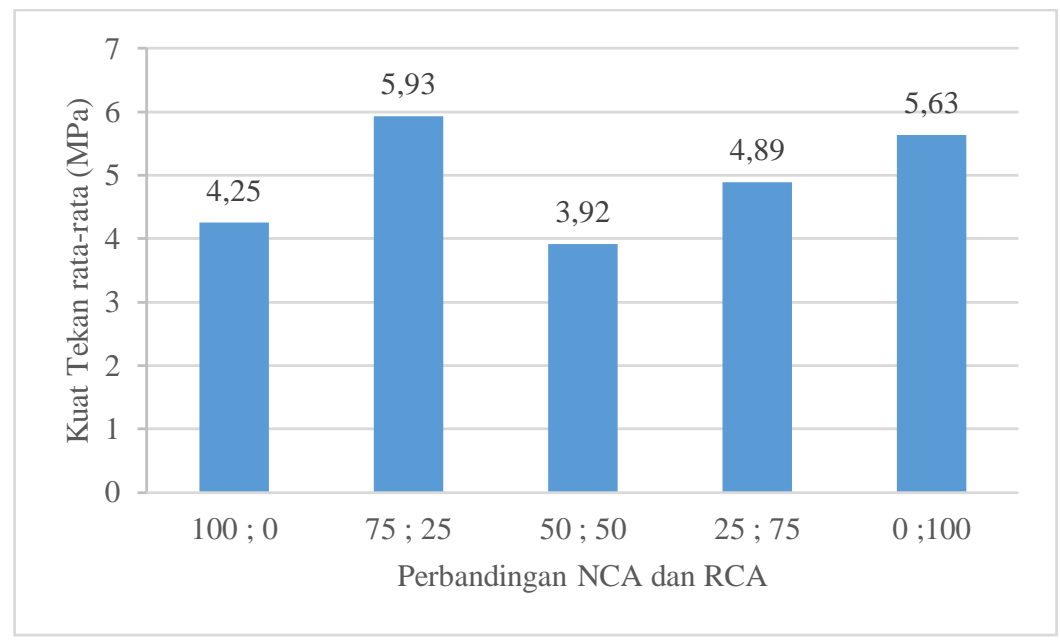

Gambar 3. Hasil uji kuat tekan rata-rata

Dari hasil penelitian diperoleh hasil kuat tekan rata-rata pada campuran $75 \%$ NCA : $25 \%$ RCA dengan fas 0,3 dan penambahan aditif 0,7\% adalah 5,93 MPa. Dari hasil penelitian ini dapat dilihat bahwa penggunaan campuran bahan aditif Sikacim Concrete Additive dapat 
meningkatkan kuat tekan pada beton. Hal ini sesuai dengan penelitian yang dilakukan oleh Yanti, G., dkk., (2021), dimana dengan melakukan variasi penambahan bahan aditif Sikacim Concrete Additive pada beton porous dapat meningkatkan nilai kekuatan benda uji beton porous hingga mencapai 18,08 MPa dan termasuk dalam kategori B yang dapat dimanfaatkan untuk pelataran parkir.

Nilai selisih uji tekan dengan komposisi agregat kasar dengan variasi perbandingan menggunakan agregat normal split dari Batu Besurat (NCA) dan agregat dari pecahan beton (RCA) seperti pada Tabel 2. Berdasarkan hasil uji, diperoleh bahwa nilai kuat tekan tertinggi pada variasi campuran $75 \%$ NCA dan $25 \%$ RCA dengan selisih kuat tekan terhadap campuran $100 \%$ NCA : $0 \%$ RCA sebesar 40\% atau 1,68 MPa, nilai kekuatan terhadap tekan terendah pada komposisi agregat kasar dangan variasi 50\% NCA:50\% RCA, terjadi penurunan kuat tekan sebesar $8 \%$ atau $0,33 \mathrm{MPa}$ terhadap campuran $100 \%$ NCA : $0 \%$ RCA.

Tabel 2. Selisih hasil uji tekan

\begin{tabular}{|c|c|c|c|c|}
\hline \multicolumn{2}{|c|}{ Komposisi Agregat Kasar (\%) } & \multirow{2}{*}{$\begin{array}{c}\text { Kuat Tekan } \\
\text { Rata-rata (Mpa) }\end{array}$} & \multicolumn{2}{|c|}{ Selisih Kuat tekan } \\
\cline { 5 - 5 } \cline { 5 - 5 } NCA & RCA & MPa & $\%$ \\
\hline$(1)$ & $(2)$ & $(3)$ & $(4)$ & $(5)$ \\
\hline 100 & 0 & 4,25 & 0,00 & $0 \%$ \\
\hline 75 & 25 & 5,93 & 1,68 & $40 \%$ \\
\hline 50 & 50 & 3,92 & $-0,33$ & $-8 \%$ \\
\hline 25 & 75 & 4,89 & 0,64 & $15 \%$ \\
\hline 0 & 100 & 5,63 & 1,38 & $32 \%$ \\
\hline
\end{tabular}

Hal ini senada dengan penelitian yang dilakukan oleh Mahdiana, Arifi, \& Nurlina (2018) pada variasi agregat ukuran $0,5 \mathrm{~cm}-1,0 \mathrm{~cm}$ kuat tekan terendah terdapat pada RCA: NCA sebesar $50 \%$ begitu pula hal nya dengan ukuran agregat 1,0-2,0 dengan nilai sebesar 4,70 MPa. Hal yang serupa juga ditemukan dalam penelitian yang dilakukan oleh Jong, Arifi, \& Waluyohadi, (2018). Dalam penelitiannya menggunakan campuran perbandingan RCA dan NCA masing masing $100: 0 ; 50: 50$ dan $0: 100$ diperoleh nilai kuat tekan tertinggi pada campuran RCA maksimum $100 \%$ dan terendah nilai kuat tekannya pada campuran RCA 50\% : NCA $50 \%$

Berat volume beton porous merupakan pengukuran massa terhadap setiap satuan volume dari benda uji beton porous seperti pada Tabel 3 .

Tabel 3. Berat volume

\begin{tabular}{|c|c|c|}
\hline \multicolumn{2}{|c|}{ Komposisi Agregat Kasar $(\%)$} & $\begin{array}{c}\text { Berat Volume Rata-rata } \\
\left(\mathrm{Kg} / \mathrm{m}^{3}\right)\end{array}$ \\
\hline NCA & RCA & 1609,88 \\
\hline 100 & 0 & 1767,9 \\
\hline 75 & 25 & 1609,88 \\
\hline 50 & 50 & 1629,63 \\
\hline 25 & 75 & 1698,77 \\
\hline 0 & 100 & \\
\hline
\end{tabular}

Berdasarkan hasil pengujian berat volume pada benda uji beton porous (Tabel 3) diperoleh nilai tertinggi pada campuran 25\% RCA : $75 \%$ NCA yaitu sebesar $1767,90 \mathrm{Kg} / \mathrm{m}^{3}$ dan nilai terendah diperoleh pada benda uji pada campuran 0\% RCA : 100\% NCA dan 50\% RCA : 50\% NCA yaitu sebesar $1609,88 \mathrm{Kg} / \mathrm{m}^{3}$. Seluruh nilai tersebut memenuhi berat volume sesuai dengan ACI 522R-10 (2010), dimana beton poroisus memiliki nilai berat jenis bervariasi dari $1602 \mathrm{~kg} / \mathrm{m}^{3}$ sampai dengan $1922 \mathrm{~kg} / \mathrm{m}^{3}$. Hal ini juga sesuai dengan penelitian yang dilakukan Harber (2005), dimana beton non pasir memiliki berat jenis sekitar 70\% terhadap beton normal.

Dari hasil pengujian dapat dibuktikan bahwa semakin banyak agregat berukuran kecil yang dimasukkan ke dalam campuran maka akan semakin padat, serta berat volume dan nilai kuat 
tekannya akan meningkat. Begitu juga dengan sebaliknya, apabila semakin banyak agregat yang berukuran besar dimasukkan ke dalam campuran maka akan semakin berongga, dan berat volume dan nilai kuat tekannya akan menurun sesuai dengan penelitian yang telah dilaksanakan oleh Megasari, dkk., (2020).

\section{Kesimpulan}

Dari hasil penelitian diperoleh kesimpulan nilai kuat tekan rata-rata tertinggi pada benda uji beton porous diperoleh pada variasi campuran 25\% Recycled Concrete Aggregate (RCA) dan 75\% Normal Concrete Aggregate (NCA) yaitu sebesar 5,93 MPa. Nilai kuat tekan rata-rata benda uji memenuhi ke dalam persyaratan kuat tekan beton porous sesuai dengan (ACI Committee $522 \mathrm{R}-10,2010$ ) yaitu berada diantara 2,8 - $28 \mathrm{MPa}$.

\section{Referensi}

ACI Committee 522 R-10. (2010). Report on Pervious Concrete (American Concrete Institute Committee 522, Ed.). diakses dari website American Concrete Institute https://www.icpi.org/sites/default/files/resources/technical-papers/1809_0.pdf

ACI Education Bulletin E1-99. (1999). ACI Education Bulletin E1-99

Badan Standarisasi Nasional. (2011). SNI 1974-2011: Cara uji kuat tekan beton dengan benda uji silinder.

Harber, P. J. (2005). Applicability of No-Fines Concrete as a Road Pavement. University of Southern Queensland.

Jamal, M., Widiastuti, M., \& Anugrah, A. T. (2017). Pengaruh Penggunaan Sikacim Concrete Additive Terhadap Kuat Tekan Beton Dengan Menggunakan Agregat Agregat Kasar Bengalon dan Agregat Halus Pasir Mahakam. Seminar Nasional Teknologi IV, (November), 28-36.

Jong, I. E. P., Arifi, E., \& Waluyohadi, I. (2018). Pengaruh Penggunaan Superplasticizer Terhadap Kuat Tekan Beton Porous Yang Menggunakan RCA (Recycle Coarse Aggregate). Jurnal Mahasiswa Jurusan Teknik Sipil, 1(2).

Kang, M., \& Weibin, L. (2018). Effect of the aggregate size on strength properties of recycled aggregate concrete. Advances in Materials Science and Engineering, 2018, 1-8. https://doi.org/10.1155/2018/2428576

Karimah, R. (2017). Pemanfaatan Limbah Pecahan Keramik Terhadap Berat Jenis dan Kuat Tekan pada Beton Ringan Ramah Lingkungan. Prosiding Seminar Nasional Teknologi Dan Rekayasa (SENTRA), 1-6.

Latjemma, S., Tahir, S., \& Haris. (2020). Studi Pemanfaatan Limbah Kulit Kerang sebagai Agregat Kasar pada Beton Normal. Jurnal Siimo Engineering, 4, 29-38.

Mahdiana, N., Arifi, E., \& Nurlina, S. (2018). Pengaruh Void Ratio dan Permeabilitas Beton Terhadap Kuat Tekan Beton Porous dengan Variasi RCA. Jurnal Mahasiswa Jurusan Teknik Sipil, 1(1), 53363.

McNeil, K., \& Kang, T. H. K. (2013). Recycled Concrete Aggregates: A Review. International Journal of Concrete Structures and Materials, 7(1), 61-69. https://doi.org/10.1007/s40069-013-0032-5

Megasari, S. W., Yanti, G., \& Zainuri. (2020). Hubungan Karakteristik Beton Porous dengan Variasi Komposisi Agregat Kasar. Prosiding Seminar Nasional Pakar, 1-17.

Nasrul, S., Yanti, G., \& Megasari, S. W. (2021). Hubungan Kuat Tekan dan Kuat Lentur pada Beton Berpori. Jurnal Rekayasa Konstruksi Mekanika Sipil, 4(1-10).

PT. Sika Indonesia. (2019). SikaCim Concrete Additive.

Ramadevi, K., \& Chitra, R. (2017). Concrete using recycled aggregates. International Journal of Civil Engineering and Technology, 8(9), 413-419.

Satrio, D. D., Yanti, G., \& Megasari, S. W. (2020). Variasi Perbandingan Semen Dan Agregat Kasar Terhadap Kuat Tekan Dan Porositas Beton Berpori. JUTEKS: Jurnal Teknik Sipil, 5(2), 95-101.

Yanti, G., Zainuri, \& Megasari, S. W. (2019). Improvement The Compressive Strength and Flexural Strength of Concrete by Adding Variations of Pineapple Leaf Fibers. TEKNIK, 40(1), 71-76. https://doi.org/10.14710/teknik.v40n1.23390

Yanti, G., Zainuri, Z., \& Megasari, S. W. (2018). Analisa Perbandingan Penambahan Variasi Consol Terhadap Kuat Tekan Beton. SIKLUS: Jurnal Teknik Sipil, 4(1), 59-66. https://doi.org/10.31849/siklus.v4i1.1155

Yanti, G., Zainuri, Z., \& Megasari, S. W. (2021). Variasi penambahan sikacim pada beton porous. Paduraksa, 10(1), 112-123. https://doi.org/10.22225/pd.10.1.2617.112-123 


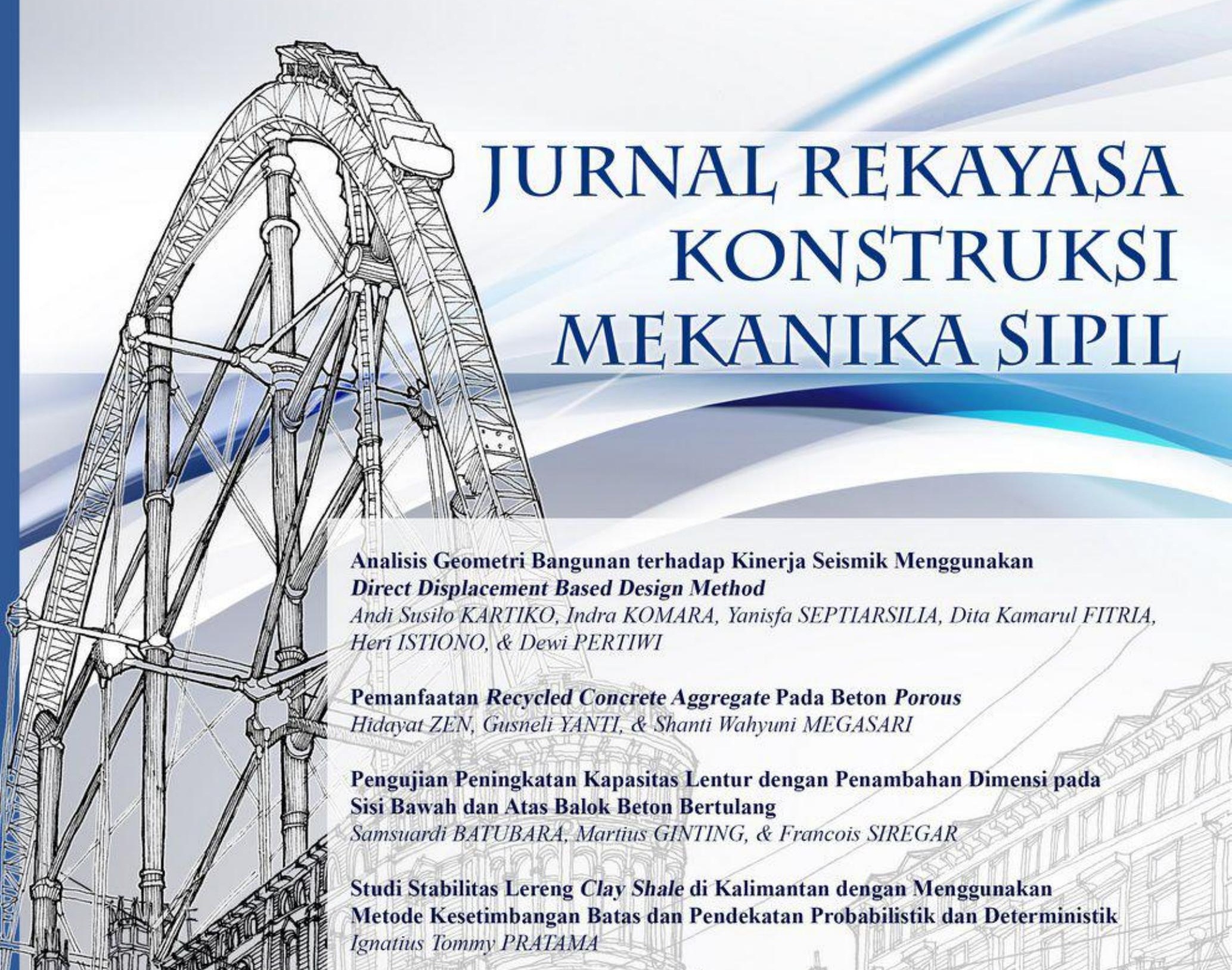

Pengaruh Tata Guna Lahan terhadap Kinerja Jalan dan Biaya Tundaan Lalu Lintas Koridor Jalan GOR Mustika Kabupaten Blora

Hartono Guntur RISTIYANTO \& Salma MFIRDAUS

Kinerja Moda Bus Trans Mebidang Trayek Lubuk Pakam-Pusat Pasar Medan di Masa Pandemi Covid-19

Oloan SITOHANG, Reynaldo SIAHAAN, \& Arnoldus Yansen Berkat LAIA

Perbandingan Produktivitas Tenaga Kerja Pembesian dan Bekisting Saat Jam Kerja Normal dan Lembur Menggunakan Metode Productivity Rating Caroline Maretha SUJANA \& Raka Aditya HAKIM

Analisis Faktor-Faktor yang Mempengaruhi Produktivitas Tenaga Kerja pada Proyek Pembangunan Jalan Tol Ruas Binjai-Langsa Seksi Binjai-Pangkalan Brandan Yolanda Ayu DAMAYANTI \& Mizanuddin SITOMPUL

Fakultas Teknik 


\section{Jurnal Rekayasa Konstruksi Mekanika Sipil (JRKMS)}

Jurnal Rekayasa Konstruksi Mekanika Sipil (JRKMS) Fakultas Teknik Universitas Katolik Santo Thomas berisi artikel-artikel ilmiah yang meliputi kajian di bidang teknik khususnya Teknik Sipil, seperti matematika teknik, mekanika teknik, analisis struktur, konstruksi baja, konstruksi beton, konstruksi kayu, konstruksi gelas, mekanika tanah, teknik pondasi, hidrologi, hidrolika, bangunan air, manajemen konstruksi, dinamika struktur, earthquake engineering, sistem dan rekayasa transportasi, ilmu ukur tanah, struktur bangunan sipil, rekayasa jalan raya, serta penelitian-penelitian lain yang terkait dengan bidang-bidang tersebut.

Terbit dalam 2 (dua) kali setahun yaitu pada bulan April dan September

\section{Penasihat :}

Prof. Dr. Drs. Sihol Situngkir, MBA. (Rektor Universitas Katolik Santo Thomas)

Ketua Penyunting (Editor in Chief) :

Ir. Oloan Sitohang, M.T. (Universitas Katolik Santo Thomas)

Manajer Penyunting (Managing Editor):

Reynaldo, S.T., M.Eng. (Universitas Katolik Santo Thomas)

\section{Anggota Penyunting (Editorial Board):}

Dr.-Ing. Sofyan S.T, M.T. (Universitas Malikussaleh)

Ir. Martius Ginting, M.T. (Universitas Katolik Santo Thomas)

Samsuardi Batubara, S.T., M.T. (Universitas Katolik Santo Thomas)

Dr. Janner Simarmata (Universitas Negri Medan)

\section{Mitra Bestari (Peer Reviewer):}

Dr.Eng. Ir. Aleksander Purba, S.T., M.T., IPM, ASEAN Eng. (Universitas Lampung, Indonesia)

Ir. Binsar Silitonga, M.T. (Universitas Katolik Santo Thomas, Indonesia)

Budi Hasiholan, S.T., M.T., Ph.D (Institut Teknologi Bandung, Indonesia)

Ir. Charles Sitindaon, M.T. (Universitas Katolik Santo Thomas, Indonesia)

Dr. Erica Elice Uy (De La Salle University, Philippines)

Dr. Ernesto Silitonga, S.T, D.E.A. (Universitas Negeri Medan, Indonesia)

Prof. Dr-Ing. Johannes Tarigan (Universitas Sumatera Utara, Indonesia)

Linda Prasetyorini (Universitas Brawijaya, Malang, Indonesia)

Dr.Eng. Mia Wimala (Universitas Katolik Parahyangan, Indonesia)

Dr.Eng. Minson Simatupang (Universitas Halu Oleo, Indonesia)

Dr. Mochamad Raditya Pradana (Keppel Marine and Deepwater Technology, Singapura)

Dr. Ir. Shirly Susanne Lumeno, S.T., M.T. (Universitas Negeri Manado, Indonesia)

Dr. Senot Sangadji (Universitas Sebelas Maret, Indonesia)

Ir. Simon Dertha, M.T. (Universitas Katolik Santo Thomas, Indonesia)

Dr. Thi Nguyên Cao (Tien Giang University, Viet Nam)

Budijanto Widjaja, S.T., M.T., Ph.D, (Guest Vol.4.No.2) (Universitas Katolik Parahyangan, Indonesia)

\section{Ilustrator Sampul:}

Yulianto, ST., M.Eng

\section{Penerbit \& Alamat Redaksi:}

Fakultas Teknik Universitas Katolik Santo Thomas

Jl. Setiabudi No. 479-F Tanjung Sari, Medan 20132

Telp. (061) 8210161 Fax : (061) 8213269

email : unika.sipil@yahoo.com 


\title{
Konten
}

\author{
REKAYASA STRUKTUR \\ Analisis Geometri Bangunan terhadap Kinerja Seismik Menggunakan \\ Direct Displacement Based Design Method \\ Andi Susilo KARTIKO, Indra KOMARA, Yanisfa SEPTIARSILIA, Dita Kamarul \\ FITRIA, Heri ISTIONO, \& Dewi PERTIWI
}

hal.

$73-84$

Pemanfaatan Recycled Concrete Aggregate Pada Beton Porous

Hidayat ZEN, Gusneli YANTI, \& Shanti Wahyuni MEGASARI

Pengujian Peningkatan Kapasitas Lentur dengan Penambahan Dimensi

pada Sisi Bawah dan Atas Balok Beton Bertulang

Samsuardi BATUBARA, Martius GINTING, \& Francois SIREGAR

\section{REKAYASA GEOTEKNIK}

Studi Stabilitas Lereng Clay Shale di Kalimantan dengan Menggunakan

Metode Kesetimbangan Batas dan Pendekatan Probabilistik dan

Deterministik

Ignatius Tommy PRATAMA

\section{REKAYASA TRANSPORTASI}

Pengaruh Tata Guna Lahan terhadap Kinerja Jalan dan Biaya Tundaan

Lalu Lintas Koridor Jalan GOR Mustika Kabupaten Blora

Hartono Guntur RISTIYANTO \& Salma M FIRDAUS

Kinerja Moda Bus Trans Mebidang Trayek Lubuk Pakam-Pusat Pasar

Medan di Masa Pandemi Covid-19

Oloan SITOHANG, Reynaldo SIAHAAN, \& Arnoldus Yansen Berkat LAIA

\section{MANAJEMEN KONSTRUKSI}

Perbandingan Produktivitas Tenaga Kerja Pembesian dan Bekisting Saat Jam Kerja Normal dan Lembur Menggunakan Metode Productivity Rating Caroline Maretha SUJANA \& Raka Aditya HAKIM

Analisis Faktor-Faktor yang Mempengaruhi Produktivitas Tenaga Kerja pada Proyek Pembangunan Jalan Tol Ruas Binjai-Langsa Seksi BinjaiPangkalan Brandan

Yolanda Ayu DAMAYANTI \& Mizanuddin SITOMPUL 


\section{Pengantar Redaksi}

Puji dan syukur kami sampaikan kepada Tuhan Yang Maha Esa karena atas kasih karuniaNYA kami dapat menyelesaikan penerbitan Jurnal Rekayasa Konstruksi Mekanika Sipil (JRKMS) Volume 4 Nomor 2, di bulan September tahun 2021 ini. Jurnal ini fokus pada beragam subbidang dalam Teknik Sipil antara lain Rekayasa Struktur, Rekayasa Geoteknik, Rekayasa Transportasi, Teknik Sumber Daya Air, dan Manajemen Konstruksi. Namun, tidak menutup kesempatan bagi subbidang lainnya yang berkaitan dengan keilmuan Teknik Sipil.

Satu hal yang patut disyukuri pula adalah semakin terkendalinya kondisi pandemi COVID-19 di Indonesia. Hal ini turut menjadi angin segar pendorong bagi kita untuk meningkatkan semangat meneliti dan berkontribusi pada bidang keilmuan kita. Pada edisi ini, kami menerima banyak artikel dengan topik yang menarik. Ada 8 peer-reviewed artikel yang terbit di Volume 4 Nomor 2 ini, yang mana terdiri atas 3 (tiga) artikel dalam topik Rekayasa Struktur, 1 (satu) artikel dalam topik Rekayasa Geoteknik, 2 (dua) artikel dalam topik Rekayasa Transportasi, 2 (dua) artikel dalam topik Manajemen Konstruksi.

Seiring dengan semakin tingginya tuntutan kualitas publikasi ilmiah oleh pemerintah, pada edisi ini tim editorial berusaha meningkatkan kualitas review dan penyuntingan dengan harapan semakin baik pula kapasitas kita bersama, dan kualitas artikel ilmiah yang kita terbitkan. Dewan redaksi menyampaikan apresiasi tinggi kepada para penulis yang tulisannya diterbitkan pada volume ini, atas kerja samanya merespon komentar dan rekomendasi dari tim editorial dan mitra bestari. Kami menyadari bahwa butuh dedikasi dan investasi waktu untuk menghasilkan karya tulis yang baik dan bermanfaat. Terkhusus, kami bersyukur atas para mitra bestari yang tidak pernah lelah dalam menyambut permintaan kami dengan penuh dedikasi.

Sebagai penutup, harapan kami adalah semoga jurnal ini dapat menjadi media ilmiah yang bermanfaat dan informatif bagi rekan-rekan dan praktisi bidang ketekniksipilan di Indonesia. Salam hangat dan Salam sehat.

Medan, September 2021

Tim Editorial 
